\title{
Impacts of Mainstream Hydropower Dams on Fisheries and Agriculture in Lower Mekong Basin
}

\author{
Yuichiro Yoshida ${ }^{1}$, Han Soo Lee ${ }^{1}{ }^{1}$, Bui Huy Trung ${ }^{2}$, Hoang-Dung $\operatorname{Tran}^{3}{ }^{\circledR}$, \\ Mahrjan Keshlav Lall ${ }^{1}$, Kifayatullah Kakar ${ }^{1}$ (D) and Tran Dang Xuan ${ }^{1, *(D)}$ \\ 1 Graduate School for International Development and Cooperation, Hiroshima University, 739-8529 \\ Hiroshima, Japan; yuichiro@hiroshima-u.ac.jp (Y.Y.); leehs@hiroshima-u.ac.jp (H.S.L.); \\ mkeshav@hiroshima-u.ac.jp (M.K.L.); kifayatullahkakar@yahoo.com (K.K.) \\ 2 Banking Faculty, Banking Academy, 100004 Hanoi, Vietnam; trungbh.hvnh@gmail.com \\ 3 Faculty of Biotechnology, Nguyen Tat Thanh University, 72820 Ho Chi Minh, Vietnam; thdung@ntt.edu.vn \\ * Correspondence: tdxuan@hiroshima-u.ac.jp
}

Received: 14 February 2020; Accepted: 17 March 2020; Published: 19 March 2020

check for updates

\begin{abstract}
The riverine ecosystems of the Mekong River Basin possess the world's most productive inland fishery and provide highly productive food crops for millions of people annually. The development of hydropower potential in the Mekong River has long been of interest to governments in the region. Among the existing 64 dams, 46 dams have been built in the Lower Mekong Basin (LMB) to produce up to $8650 \mathrm{MW}$ of electricity. Additionally, of the 123 proposed built hydropower dams, eleven hydropower plants have been nominated for the river mainstream and are expected to install a total of 13,000 MW in the LMB countries. However, serious concerns have intensified over the potential negative economic consequences, especially on fisheries and agriculture in Cambodia and Vietnam. To date, most of the concerns have concentrated on the impacts on hydrology, environment, livelihood, and diversity in the LMB attributed to hydropower development. This paper, however, discusses the fishery and agricultural sectors of the LMB and focuses on the downstream floodplains of Cambodia and Vietnam. The dam construction has caused greater losses of biodiversity and fisheries than climate change in the LMB. The reduction of 276,847 and 178,169 $\mathrm{t}$ of fish, $3.7 \%$ and $2.3 \%$ of rice, $21.0 \%$ and $10.0 \%$ of maize will contribute to a decrease of $3.7 \%$ and $0.3 \%$ of the GDP of Cambodia and Vietnam, respectively. Lao PDR may benefit the most revenue from electricity generation than the other country in the LMB, as most of the proposed dams are projected in the country. Cambodia burdens 3/4 of the reduction of total capture fishery destruction, whilst Lao PDR, Thailand, and Vietnam endure the remaining 1/3 losses. The tradeoff analyses reveal that losses of capture fisheries, sediment or nutrients, and social mitigation costs are greater than the benefits from electricity generation, improved irrigation, and flood control of the LMB region. The socioeconomic and environmental damage caused by hydropower dams in developing countries, including the Mekong, is greater than the early costs in North America and Europe. It is proposed that dam construction for hydropower in the Mekong River, as well as other rivers in developing countries, should be gradually removed and shifted toward solar, wind, and other renewable resources.
\end{abstract}

Keywords: Mekong River; economic impacts; tradeoff; aquaculture; floodplain; Tonle Sap; migration barrier 


\section{Introduction}

The dam construction on the mainstream of the world's major rivers, experienced in Mississippi, the Yangtze, the Nile, the Yellow, the Congo, as well as the Mekong, has caused losses of wetlands, flood disasters, and poor water quality, agriculture and fishery production, and biodiversity [1]. In developing countries, hydropower production has been developing rapidly, and may increase by more than $70 \%$ in the next few decades [2]. This is affecting aquatic biodiversity and agricultural production in the Amazon, Congo, Mississippi, Yangtze, Nile, and Mekong [3]. From 37,600 dams higher than $15 \mathrm{~m}$, more than 8600 dams worldwide primarily designed for hydropower generation are in operation [4]. There are 32 countries, including Brazil, Mozambique, Nepal, and Norway, that currently use hydropower to produce over $80 \%$ of their electricity requirements [4]. An estimated 3700 dams that produce $>1 \mathrm{MW}$ are either planned or under construction in developing countries [1]. Hydropower currently presents $71 \%$ of global production of renewable energy [5] and only $22 \%$ of the global potential has been exploited to date [4]. Thus, there is a recent trend of building new large hydropower dams in developing countries, particularly in megabiodiversity river basins, such as the Amazon, the Congo, and the Mekong, although enormous loss in these ecologically important regions is being occurred [1,6-9]. There were 80 million people displaced in the last century because of dam instruction [10]. The fish catch in the Tucurui Dam region of the Brazilian Amazon declined by $60 \%$ and over 100,000 people living downstream were affected by the loss of fisheries, flood recession agriculture, and other natural resources [10]. In the Niger and Volta rivers in West Africa, and Congo and Ogooue rivers in Central Africa, the increase of dam construction is affecting agricultural production and ecosystems [11].

The Mekong River is the longest river in Southeast Asia and the $12^{\text {th }}$ longest in the world. Rising in Tibet, it flows for about 4,350 km through China, Myanmar, Lao PDR, Thailand, Cambodia, and Vietnam before draining into the South China Sea (Figure 1). The river watershed covers about 795,000 $\mathrm{km}^{2}$, and includes the Upper Mekong Basin (UMB) and the Lower Mekong Basin (LMB). The UMB surrounds territories of China and Myanmar while the LMB makes up three-fourths of the drainage basin, including Lao PDR, Thailand, Cambodia, and Vietnam [12]. According to the Mekong River Commission (MRC) [13], the LMB supports nearly 60 million residents of which about $50 \%$ live within $15 \mathrm{~km}$ of the riverbanks, and can provide sustained livelihoods, food security, and rich ecosystem services for millennia [14,15]. The Mekong River is the largest freshwater fishery in the world [16]. The fish catch was about 2.0-2.6 million $t$ annually [17]. The bio-diverse system for fish species of the Mekong River places only after the Amazon and Congo rivers, with approximately 800 fish species [18]. Fish is the principal source of protein for the local people, accounting for $49 \%-82 \%$ of animal protein consumed $[19,20]$.

The Mekong could produce over 30,000 MW of electricity, however, only about $10 \%$ of this potential has been developed so far [12,13]. A total of 11 hydropower dams are proposed for the Mekong River mainstream. 


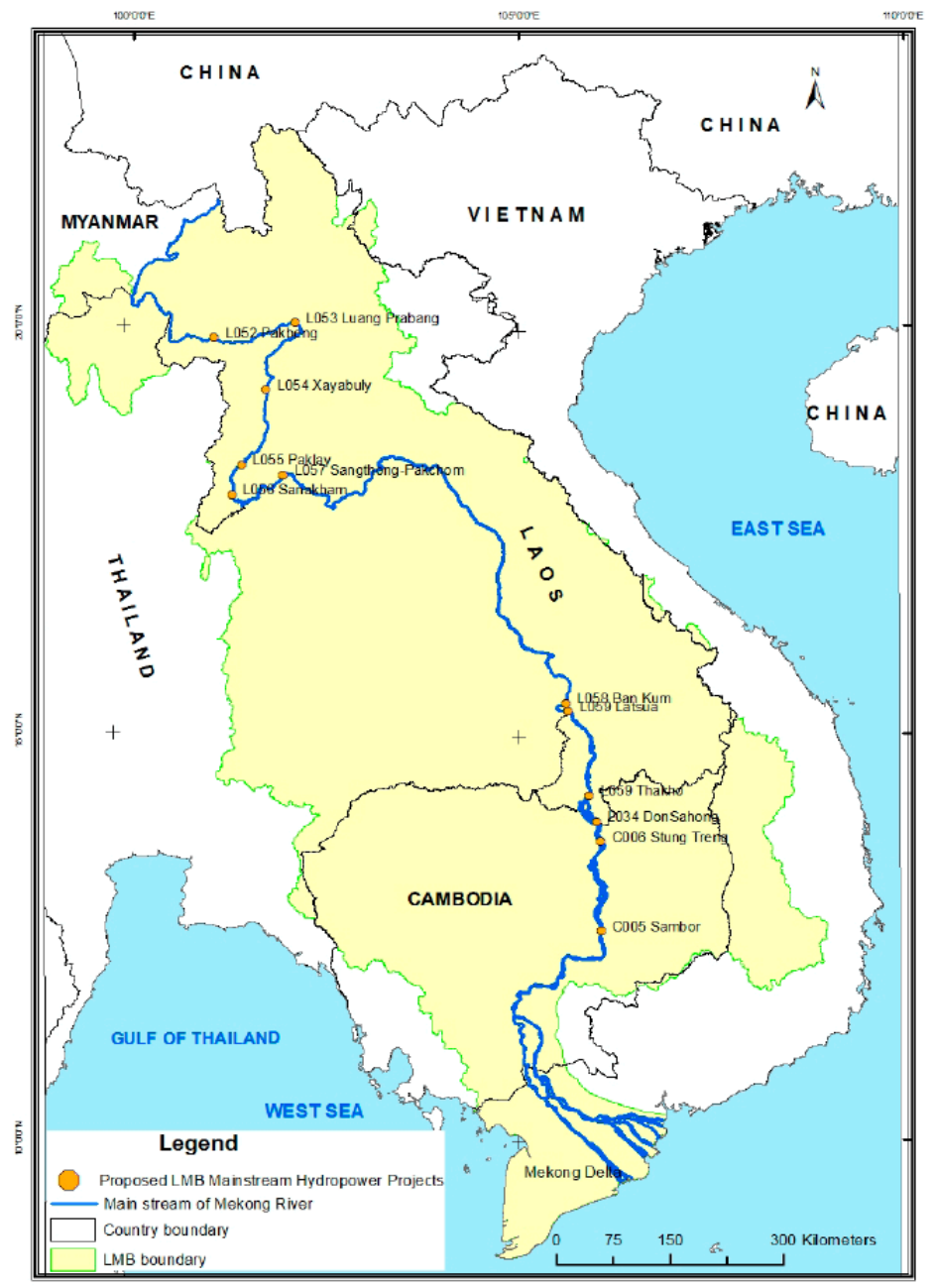

Figure 1. Location of proposed Lower Mekong Basin (LMB) mainstream hydropower projects [21].

Today, the Upper Mekong River in China is controlled by many dams and reservoirs, which have strongly altered navigation patterns and the flow of water and sediment to the Mekong Delta. In the south, Lao PDR is constructing a hydroelectric dam and planning a series of other dams $[5,22]$. There has been an increase in power demand in these regions, and future demand is forecasted to be even greater. Volatile prices in international energy markets have intensified interest in hydropower development [22-25]. Governments, especially Lao PDR, have harbored potential earnings from hydropower development for reducing poverty, lowering national debts, supporting economic growth as well as achieving regional energy security. On the other hand, it is argued that the proposed dams might cause significant and negative effects on fisheries and agriculture of the LMB [22-25]. The benefits from hydropower generation may provide 6-32 billion USD but the potential damage from fisheries capture may reach $2-13$ billion USD [13,25]. To date, how fisheries and agriculture related to 10 million people in the downstream areas are affected by these changes has not been studied enough. In addition, only a few studies have concentrated on hydrological alternations and the socioeconomic impacts in the LMB [26,27]. Fan et al. [28] and Yu and Geheb [29] evaluated the hydrological impacts of Chinese hydropower dams in the UMB. Several integrated modeling approaches to assess the socioeconomic and ecological impacts from dam instructions on the Mekong River basin were conducted [28-31].

The Lower Mekong floodplain in Cambodia and Vietnam is believed to experience severe impacts from the hydrological changes due to its dense population who depend highly on fisheries and flood recession agriculture, especially rice $[12,25,26]$. In Cambodia, 10 provinces are a part of the main component of the river basin, with about $86 \%$ of the population living in this region $[25,26]$. In Vietnam, 
the Mekong Delta consists of 11 provinces and around 3.9 million ha of land. Of this, 3.3 million ha are either agricultural or forestry lands, and 1.9 million ha of that is paddy fields [32] (Figure 2, Map of districts in the Basin). The impacts of building dams on the tributaries of the LMB have also been discussed recently [3].

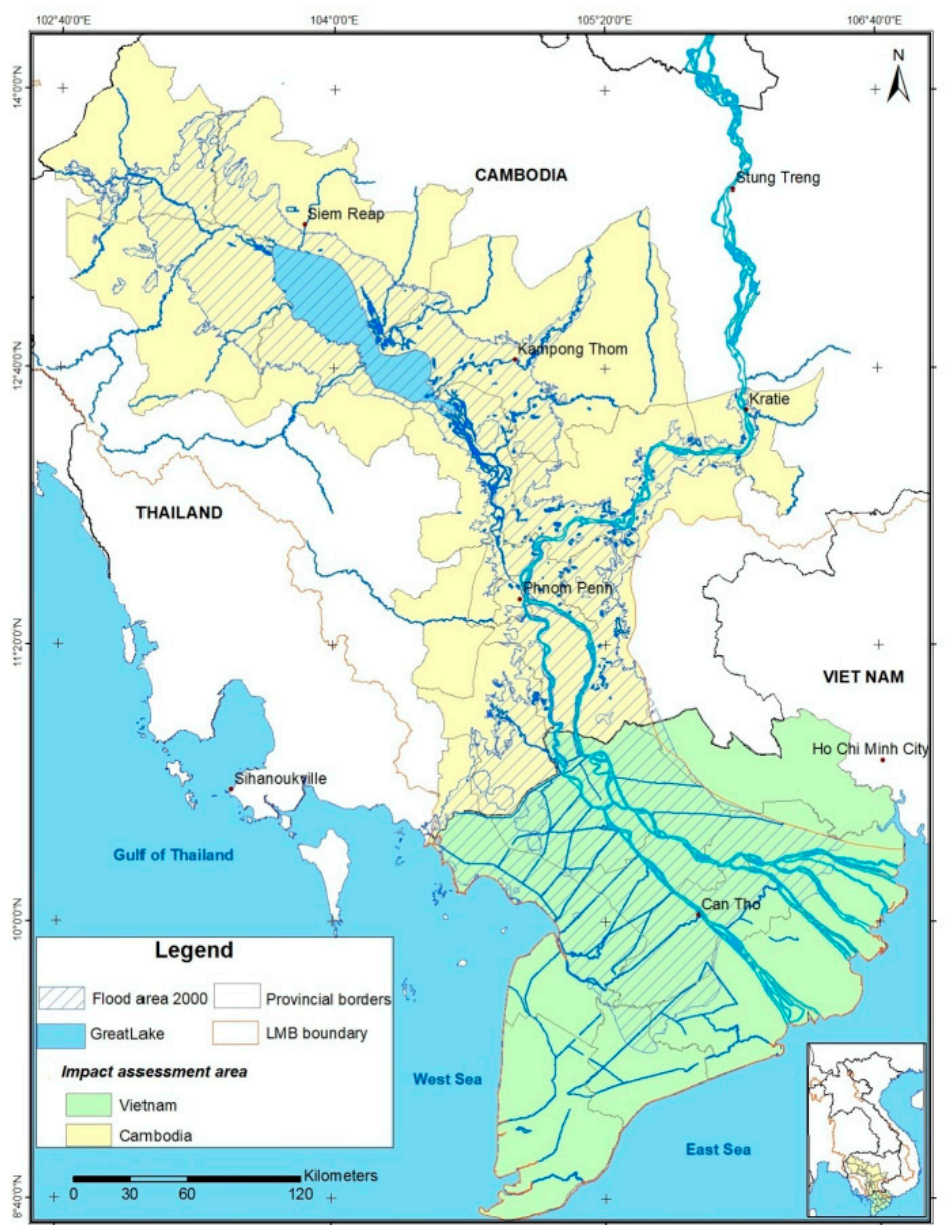

Figure 2. Surveyed regions in the Lower Mekong Basin [21].

The construction of dams on the LMB has attracted much research, but it is more focused on hydrology, power generation, climate change, sediment deficit, and floodplain habitat than agriculture or fisheries. Therefore, this study aims to discuss the potential and actual influence on fisheries and agriculture caused by both the existing and proposed hydropower dams on the mainstream of the LMB. How fisheries and agriculture of the LMB are influenced by construction of the proposed mainstream hydropower projects and an evaluation of the economic impacts on these sectors and on the countries in the LMB are detailed. Useful information from the survey and modeling results on approximately 106,400 $\mathrm{km}^{2}$, consisting of 13 provinces in Vietnam and 14 provinces in Cambodia during 2012-2015 (Figure 2), is provided in this paper [21]. It is combined with existing knowledge from recent reports $[2,12,25]$ regarding projected hydrological alternations caused by hydropower dams on both Mekong mainstream and tributaries. At first, we provide an overview of the potential influence of dams over the LMB on fisheries and agriculture and the key findings of the recent literature on this issue. The aggregate economic impacts at both regional and national levels attributed to the losses from agriculture and fisheries are discussed. Potential solutions to reduce the detrimental effects of building dams in the LMB on agriculture and fisheries of the region are also proposed. 


\section{The Proposed Eleven Hydropower Dams in the Mekong River Mainstream}

The 11 dams proposed on the mainstream of the Mekong River by various developers will cover from Pak Beng (Lao PDR) to Sambor (Cambodia), have 240-2,600 MW power capacity, enclose 0.29-620.5 km2 in their reservoir, and relocate 66-19,034 residents in total (Table 1) [21].

Table 1. Information on the location, power capacity, reservoir capacity, and relocated residents of the 11 proposed dams in the LMB [21].

\begin{tabular}{|c|c|c|c|c|c|c|}
\hline No & Project & Location & Proposed Developer & $\begin{array}{l}\text { Power } \\
\text { Capacity } \\
\text { (MW) }\end{array}$ & $\begin{array}{l}\text { Reservoir } \\
\text { Area }\left(\mathrm{km}^{2}\right)\end{array}$ & $\begin{array}{l}\text { Relocated } \\
\text { Residents }\end{array}$ \\
\hline 1 & Pak Beng & Pak Beng town, Lao PDR & China Datang Cooperation & 1200 & 87 & 6700 \\
\hline 2 & $\begin{array}{l}\text { Luang } \\
\text { Brabang }\end{array}$ & Luang Brabang town, Lao PDR & Petro Vietnam Power Services & 1100 & 55.9 & 10,264 \\
\hline 3 & Xayaburi & $\begin{array}{l}150 \mathrm{~km} \text { downstream of Luang } \\
\text { Brabang town, Lao PDR }\end{array}$ & CK Power PLC, Thailand & 1280 & 55.9 & 2130 \\
\hline 4 & Pak Lay & Pak Lay town, Lao PDR & CIEC and Sinohydro of China & 1320 & 108 & 6129 \\
\hline 5 & Sanakham & $\begin{array}{l}\text { Between Loei and Vientiane } \\
\text { provinces, Lao PDR }\end{array}$ & China Datang Cooperation & 700 & 81 & 4000 \\
\hline 6 & Pak Chom & $\begin{array}{l}\text { Shared between Thailand and Lao } \\
\text { PDR, } 100 \mathrm{~km} \text { upstream of } \\
\text { Vieantiane, Lao PDR }\end{array}$ & $\begin{array}{l}\text { Not yet, pre-feasibility studies } \\
\text { commissioned by Thailand } \\
\text { and Lao PDR governments }\end{array}$ & 1079 & 74 & 535 \\
\hline 7 & Ban Koum & $\begin{array}{c}\text { Shared between Thailand and Lao } \\
\text { PDR, } 10 \mathrm{~km} \text { above the confluence } \\
\text { of the Mun/Chi river with the } \\
\text { Mekong }\end{array}$ & Ital-Thai, Thailand & 1872 & 133 & 935 \\
\hline 8 & Lat Sua & $\begin{array}{l}\text { Between Pakse and the Mun/Chi } \\
\text { confluence, Thailand }\end{array}$ & $\begin{array}{c}\text { Charoen Energy Water Asia } \\
\text { Co., Thailand }\end{array}$ & 686 & 13 & None \\
\hline 9 & Don Sahong & Hu Sahong, Thailand & $\begin{array}{l}\text { Mega First Corporation } \\
\text { Berhad, Malaysia }\end{array}$ & 240 & 0.29 & 66 \\
\hline 10 & Stung Treng & Stung Treng town, Cambodia & $\begin{array}{c}\text { Vietnam Urban and Industrial } \\
\text { Investment Cooperation, } \\
\text { Vietnam }\end{array}$ & 900 & 211 & 10,000 \\
\hline 11 & Sambor & Sambor village, Cambodia & $\begin{array}{c}\text { China Guodian Corporation, } \\
\text { China }\end{array}$ & 2600 & 620.5 & 19,034 \\
\hline
\end{tabular}

In 2008, the total active storage capacity of reservoirs in the Mekong River basin was $8.6 \mathrm{~km}^{3}$, or $2 \%$ of its annual discharge [33,34]. The basin can activate the reservoir storage to $86.8 \mathrm{~km}^{3}$ by 2025 , approximately $20 \%$ of its annual discharge [24,34]. However, the existing and planned dams in China were not counted [35], which shows the active and dead storage of $8.7 \mathrm{~km}^{3}$ by 2025 . There are 64 existing and 187 proposed hydropower dams with an installed capacity of over $15 \mathrm{MW}$, which have been commissioned by June 2017 [12]. From the 64 dams, 17,700 MW (over 91\%) of power is provided by the 18 located on the UMB mainstream. The other 46 dams in the LMB tributary can generate up to $8650 \mathrm{MW}$ [12]. With exception of the controversial 11 proposed dams in the LMB mainstream, which can provide up to 13,000 MW [35], the total installed capacity of both existing and proposed dams in the Greater Mekong Dam Database (GMDD) may exceed 65,000 MW, although other reports highlighted that it may reach from 59,000 MW [36] to 88,000 MW [37]. On the existing dams in the

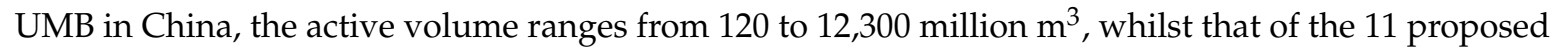
dams in the LMB is 115-1,450 million $\mathrm{m}^{3}$ (Table 1). The operation of dams in the UMB is either seasonal or yearly, but all of the 11 proposed dams in the LMB are planned to operate daily. The mean annual flow of dams in the UMB is 31,060-58,030 million $\mathrm{m}^{3} / \mathrm{year}$, but that of the 11 proposed dams in the LMB has greater value $\left(96,500-432,500\right.$ million $\mathrm{m}^{3} /$ year) (Table 2$)$. 
Table 2. Information on the existing dams in the Upper Mekong Basin (UMB) in China and the 11 proposed dams in the LMB.

\begin{tabular}{|c|c|c|c|c|c|c|c|}
\hline Project & $\begin{array}{c}\text { Full } \\
\text { Supply } \\
\text { Level (m) }\end{array}$ & $\begin{array}{c}\text { Lowest } \\
\text { Supply } \\
\text { Level (m) }\end{array}$ & $\begin{array}{c}\text { Active } \\
\text { Volume } \\
\left(\text { million } \mathrm{m}^{3}\right)\end{array}$ & $\begin{array}{c}\text { Inactive } \\
\text { Volume } \\
\left(\text { million } \mathrm{m}^{3} \text { ) }\right.\end{array}$ & $\begin{array}{c}\text { Mean Annual } \\
\text { Flow (million } \\
\mathrm{m}^{3} / \text { year) }\end{array}$ & $\begin{array}{c}\text { Mean Active } \\
\text { Storage } \\
\text { Time (d) }\end{array}$ & Operation \\
\hline \multicolumn{8}{|c|}{ Chinese } \\
\hline Gongguoqiao & n.a & n.a & 120 & 240 & 31,060 & 1.4 & Seasonal \\
\hline Xiaowan & 1235 & 1166 & 9900 & 4660 & 38,470 & 96.9 & Yearly \\
\hline Manwan & 899 & 888 & 257 & 663 & 38,800 & 2.5 & Seasonal \\
\hline Dachaoshan & n.a & n.a & 467 & 423 & 38,790 & 4.4 & Seasonal \\
\hline Huozhadu & 810 & 760 & 12,300 & 9400 & 55,190 & 81.3 & Yearly \\
\hline Jinghon & n.a & n.a & 249 & 891 & 58,030 & 1.6 & Seasonal \\
\hline \multicolumn{8}{|c|}{ Lao PDR/Cambodia } \\
\hline Pakbeng & 345 & 340 & 442.4 & 1295 & 96,500 & 1.67 & Daily \\
\hline Luang Prabang & 310 & 300 & 734 & $1,311.7$ & 100,000 & 2.63 & Daily \\
\hline Xayaburi & 275 & 270 & 738.1 & 78.3 & 124,000 & 2.16 & Daily \\
\hline Paklay & 240 & 235 & 383.5 & 967.8 & 130,700 & 1.07 & Daily \\
\hline Sanakham & 215 & 210 & 206.1 & 61.7 & 133,800 & 0.56 & Daily \\
\hline Pakchom & 192 & 190 & 440.9 & 656 & 141,600 & 1.10 & Daily \\
\hline Ban Kum & 115 & 110 & 651.5 & 1458.5 & 294,600 & 0.81 & Daily \\
\hline Latsua & 97.5 & 90.0 & 550 & 1000 & 294,600 & 0.68 & Daily \\
\hline Don Sahong & 75.1 & 71.0 & 115 & 476 & 325,100 & 0.13 & Daily \\
\hline Stung Treng & 52.0 & 51.0 & 150.8 & 518 & 405,800 & 0.14 & Daily \\
\hline Sambor & 40.0 & 38.0 & 1450 & 4001.1 & 432,500 & 0.98 & Daily \\
\hline
\end{tabular}

Among the proposed dams, Sayaburi, with about $32 \mathrm{~m}(100 \mathrm{ft})$ height and $1280 \mathrm{MW}$ power (Table 1), has caused much concern by member countries regarding changes in the river pulse and downriver effects on sediment distribution and water quality, and their environmental and human impact [22]. Lao PDR has aimed to sell hydroelectricity to Thailand, Myanmar, China, Cambodia, and Vietnam by building the proposed dams, as mentioned above. Of these dams, Xayaburi will be the first dam south of the China border constructed across the main stem of the Mekong River in Lao PDR. Thus, there is a worldwide concern that the Xayaburi dam could lead to the construction of more dams across the Mekong River [22]. This dam may directly affect 202,000 people along the Mekong River, and push endangered fish such as Mekong giant catfish to extinction [22].

\section{Impacts on Fisheries}

The inland fisheries of the Mekong basin are among the largest in the world and are a lifeline for the people in the region. Fisheries are the main occupation for Mekong's population and are considered as a source of important food and nutrition. Many people in the LMB countries still depend upon local fishery products for food security. In Vietnam, the Mekong Delta is the most important fishery for approximately $40 \%$ of the total national production. The fishery production in Mekong Delta has risen from 552,240 $t$ in 1995 to more than one million $t$ in 2013 [21]. In Cambodia, the Great Lake and Tonle Sap contribute $60 \%$ of the annual commercial fishery production of the country. Fish and other aquatic products not only contribute greatly to the nation's food security, but also become a great environmental asset. As the population of the LMB is predicted to grow to over 100 million by 2025 , the dependence on the fishery sector will increase. If the productivity of the fishery declines, or if fishery products are contaminated with industrial waste, the consequences could be severe [13].

Large dams have had well-documented negative impacts on inland fisheries throughout the world [37-40]. Such impacts are also documented for some dams in the LMB [12,21,27,41,42]. Dams create reservoirs that may support large fisheries, but the overall effect of large dams is usually a loss of fish production $[16,24,43]$. It has been shown that fisheries in the Mekong Delta are principally controlled by flow regime, nutrient dynamics correlated with transport and removal of sediments, and barriers to migration [38]. Meanwhile, proposed hydropower developments could potentially lead to the shift in river flow regimes, sediment and nutrient transport, and water quality [21]. These potential changes would be directly harmful to habitat, populations and communities, foraging and breeding behaviors, species interactions and ecosystem functioning, and migration of fishes. 
Furthermore, mainstream hydropower development would affect fish migration, spawn distribution and downstream drift of larval and juvenile fishes [1,5,44,45].

The new dam-reservoir ecological system may alter fish species and abundance, fishing techniques, and uses of river resources. The Mekong River is the seventh longest in Asia and the longest in Southeast Asia with the most productive inland fishery [5] and has many important fish species such as the Mekong catfish (Pangasianodon gigas), the giant barb (Catlocarpo siamensis), Julien's golden carp (Probarbus julieni), and two probarbids (Probarbus labeamajor and Probarbus labeaminior) [44]. Laotians and Cambodians catch more freshwater fish per capita than any other people worldwide [45]. There were 877 fish species in the Mekong River Basin (not consisting of estuary marine species), of which regional species richness ranges from 484 species in the Mekong Delta to only 24 species in the Chinese headwaters [16]. It was documented that as many as 103 of these species are potentially impacted by hydropower development [6]. There is a $0.3 \%$ ( 1700 $\mathrm{t} / \mathrm{year})$ decrease of fish biomass for each additional terawatt hour per year (TWh/y) up to $\sim 14 \mathrm{TWh} / \mathrm{y}$. The sale of fish and fishery products contributes to about $25 \%$ of Southeast Asia's rural incomes in general and accounts for up to $40 \%$ of households' income in the Tonle Sap area [16]. The completion of all proposed dams in the Mekong River and tributaries would have catastrophic impacts on fish productivity and biodiversity [16].

\subsection{Impacts on Capture Fisheries}

The capture fisheries of the LMB have a centuries-long history of local resource knowledge, catch technology, fish processing, marketing, and social organization. Construction of dams, weirs, or diversions which act as physical barriers to fish migrations is one of the major threats to sustaining capture fisheries in the LMB [46]. The impacts of dams on capture fisheries are varied, often profound and typically mediated through several major pathways, including change in the expansion of flooding area, flow modifications, hydro-peaking, sediment reduction, barrier and reservoir influences, and salinity penetration. It is possible to calculate these factors separately and then add the results to arrive at a rising impact projection.

\subsubsection{Influences of Habitat Alteration on Fish Capture Yields}

Most fish species depend on different habitats at particular stages of their life and different seasons of the year [15,18-20,37]. During the flood season, most Mekong fish species take advantage of the floodplains for feeding, breeding, and rearing their young. Outside the flood season, fish stay in dry-season refuge habitats, mainly in permanent lakes and pools or within river channels [16,18-21,38]. It is argued that mainstream hydropower development could result in the alternation of the spreading of principal fish habitats in the LMB [21]. In detail, the total reduction in fish production for the Mekong Delta, Cambodian alluvial plains, and Tonle Sap is about 1,206 t, 2,572 t, and $56.0 \mathrm{t}$ annually, respectively. The predicated losses of other aquatic animals (OAAs) are $227 \mathrm{t}, 462 \mathrm{t}$, and $10.5 \mathrm{t}$, respectively, totaling $700 \mathrm{t}$ [21].

\subsubsection{Impacts of Flow Modification on Fish Capture Yields}

The hydrological cycle is another factor that is likely to have an influence on the aquatic species that inhabit the Mekong River and alluvial plains. The timing, extent, and duration of flooding affect recruitment in fish communities and somatic development $[12,47,48]$. The recruitment and growth respond emphatically to longer and greater inundation extent because more larvae are shifted to alluvial plains with habitat and benefit from more favorable feeding times [12,47,48].

The flow dynamics are, therefore, believed to have an influence on productivity and diversity of river capture fisheries (Figure 3). Change in water level might force the fish to move on to the alluvial plains and fishers intercept these fish during their migration [48]. Another reason is the reproduction of gears and efforts to capture the fish while accessible on the alluvial plain. In addition, part-time fishers in the region favor operating during the flood season while they work on fields during the dry and transitional seasons [48]. 


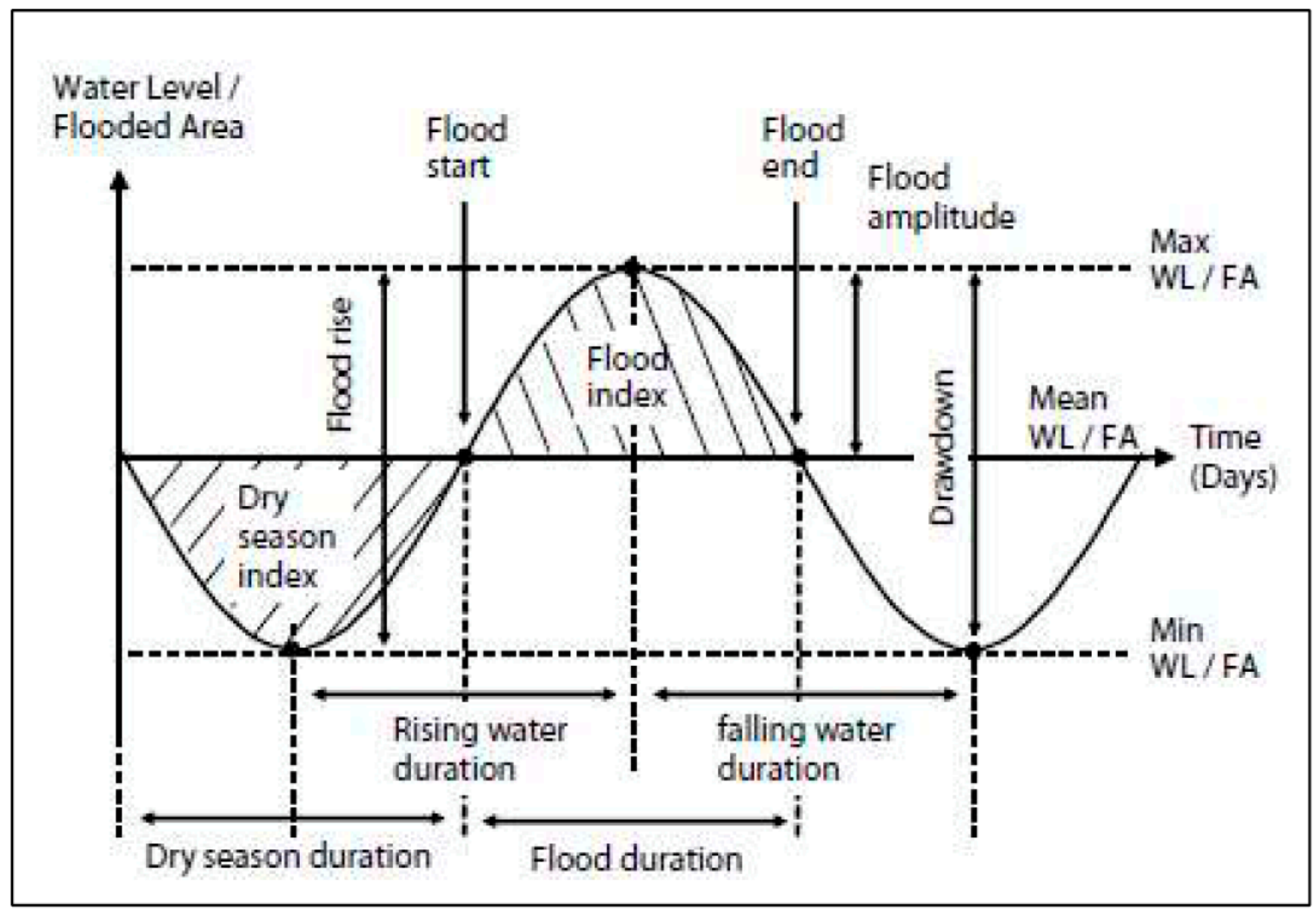

Figure 3. Estimation of inundation hydrological indicators [48].

The hydrological changes that would capably affect fish and fisheries at two places on the LMB, including Tan Chau (Vietnam) and Prek Kdam (Tonle Sap, Cambodia) regions, were investigated [21]. The study concluded that there is no potential from remarkable divergence in the timing and frequency of the inundating pattern due to the operation of these dams.

\subsubsection{Hydro Peaking Impacts on Fish Capture Yields}

Hydro peaking refers to different discharge and downstream water heights due to the release of water retained in the storage basin to generate electricity for market demand [41]. As a result, when energy demand becomes high during the day time, the power production is escalated depending on the power of large downstream flows. In contrast, the power production will be reduced at night time, which is accompanied by much lesser discharge [49,50].

The effect of hydropeaking on the net capture of fish has been surveyed extensively. The availability and appropriateness of aquatic habitat including fish and other aquatic organisms are remarkably varied by large, frequent, and rapid fluctuations in downstream of a dam [51]. This problem can cause negative effects on both habitats and aquatic organisms [51,52]. Furthermore, hydropeaking may result in large changes in water depth, flow velocity, wetted area, river channel morphology, and the quantity and composition of suspended matters and water temperature [53]. A considerable number of aquatic organisms, including drift of macroinvertebrates and stranding of fish and alternations of their habitat, would be affected [54].

Another problem is that in many regulated rivers, the man-made variations in riverine hydrology will gradually exterminate natural adaptations of aquatic organisms. The hydropeaking flows decline fish populations, including the reduction of macro-invertebrate species [55]. When the invertebrate communities are destroyed, the fish assemblages will also be strongly affected as they assemble the nutritional basis for rich fish species [56]. Hydro peaking has been found to destroy the aquatic biota by slashing the species number, biomass, and diversity, and altering the composition of fish communities [53-56]. 
The construction of enormous dams across the mainstream of the Mekong River is controlled by hydropeaking power production, therefore, flows will be bolstered during the day. These hydropeaking-induced flow modifications could potentially lead to serious environmental impacts on the river habitats between Sambor and as far downstream as Phnom Penh [21]. Major consequences could decrease fish production, which includes the reduction in reproductive output and disruption in upstream shift of adult fishes $[12,47,48]$. In addition, the rhithron fish species which make their habitat around Kratie (Cambodia) may be strongly reduced in number and face extinction in the region. Furthermore, the changed hydrology will constraint the migration of adult fishes, destroying their behavioral migration cue cycles. In addition, fishing in that area could be more difficult because of the changes in water levels. Simultaneously, the livelihoods of local residents downstream of the Mekong River, which are heavily dependent on fishing, will likely be influenced.

In general, hydropeaking would potentially have a measurable influence on fish production in the LMB. However, it is challenging to quantify these effects. This is because there is a lack of information about the fisheries in the Kratie region (Cambodia). The effects on fish yield from hydropeaking are measurable but the barrier effect of the dams would result in a much greater effect [21].

\subsubsection{Impacts of Sediment Loss on Fish Capture Yields}

Hydropower development by building dams on the mainstream of the Mekong River will cause significant loss of sediment delivery to the alluvial plains in Cambodia and Vietnam, which will be linked to a loss in fish capture yields. The annual sediment from the upstream delivered to the deltas in Cambodia and Vietnam provides rich nutrients and helps to maintain habitats. The reduction of phosphorus and nitrogen from the carried sediment might be lost up to $90 \%$ and $20 \%$, respectively [21]. The loss of sediment firstly affects the crop productivity of deltas and vulnerably influences the fishery production of the regions [36,50]. However, to date, the dependence of the fishery capture and biological productivity in the Mekong River on sediment loads has not been well surveyed and understood.

Different declines of sediment input with the total fish biomass from the Mekong River were modeled $[57,58]$. If the sediment is reduced by $80 \%$, up to $36 \%$ of total fish production might be lost. In the research of VNMRE [21], which implemented a simple proportional model to calculate and relate the reduction of sediment to the decrease of primary and secondary and whitefish yield, the loss in fishery productivity was significantly proportional to the amount of disappeared bioavailable phosphorus from the sediment loaded to the Mekong Delta in Cambodia and Vietnam. In detail, about $47 \%$ of sediment loss was recorded in Kartie (Cambodia), whilst the latter $46 \%$ was noted in Tan Chau and Chau Doc regions (Vietnam). This research also revealed that an amount of $88 \%$ phosphorus and $28 \%$ nitrogen was associated with silt and clay fractions [21]. The total number of white, black, and grey fishes accounts for $37 \%, 13 \%$, and $50 \%$, respectively [36]. White fishes belong principally to Cyprinidae and Pangasiidae, whilst black fishes are Channidae, Clariidae, Bagridae, Anabantidae and Osphronemidae and grey fishes refer to some species from Siluridae and Notopteridae. In addition, the black fish, which has been exploited in the alluvial plains of the Mekong Delta is also potentially lost. This research also documented that a total of $30.98 \%(102,875 t)$ and $42.25 \%(106,998 t)$ of fish capture yields in Cambodia and Vietnam floodplains will be reduced, respectively, due to the sediment loss. As a result, fish productivity in Tonle Sap's alluvial plain will also be affected [21].

The sediment loss will also affect the maintenance of the habitat integrity for fisheries in the downstream deltas in Cambodia and Vietnam [33]. This shoreline change will cause significant erosion and damage the coastal mangroves. The net influence of such mangrove reduction will vulnerably affect the habitat fish and crustaceans [59].

\subsubsection{Impacts of Longitudinal Connectivity Disruption on Fish Capture}

The freshwater fish species in the Mekong River, especially in Cambodia and Vietnam have various life cycles. Many fish species are required to migrate upstream to spawning areas. Many commercially valuable white fish migrate long stretches from the middle regions of the Mekong River 
to the Cambodian floodplain [58]. The annual migration of fish requires unhindered passage upstream and quantities of adults, larvae, and juveniles to journey and drift downstream.

However, the presence of the proposed 11 dams in the mainstream of Mekong Delta will disturb the access of fish to upstream and downstream spawning, as well as nursery, feeding, and living habitats $[58,59]$. The construction of these dams will also alter the seasonal flows through all six countries bearing the Mekong River, which also vulnerably influences both rice production in the delta of Vietnam and the Tonle Sap lake in Cambodia, and many species of fish migration from Cambodia to Vietnam and vice-versa. The fish population in the Mekong River may be affected by $60-90 \%$ due to the constraint from passing the mainstream dams in the Mekong River [47,48].

In addition, two cases of fish migration are in danger of experiencing yield losses by up to $100 \%$ and $80 \%$, due to the barrier effects of the proposed dams. The white fish production at the $100 \%$ loss might reach 276,847 $\mathrm{t}$ and 178,169 $\mathrm{t}$ for Vietnam and Cambodia, respectively. In the case of white fish loss by $80 \%, 286,129 \mathrm{t}$ and 208,791 $\mathrm{t}$ might be reduced in Vietnam and Cambodia respectively [21]. The total loss of fish caused by dams on the Mekong mainstream might reach 0.7-1.6 million $t$ annually $[60,61]$.

\subsection{Impacts on Aquaculture}

Aquaculture is one of the most important businesses for farmers in the Mekong Delta region. Aquaculture in the LMB region is the principal economic activity to increase the productivity of foods as well as income for farmers [21,43]. The total area for aquaculture production is 750,000 ha, however, the land for aquaculture is principally located coastal provinces, which includes the production of shrimp and prawn [21]. The aquaculture production in the Mekong Delta has been increasing in the last 20 years and the cultivation area has stabilized in the last 10 years. The cultivation of Pangasius, a major freshwater fish in the region, has increased rapidly $[21,43,45]$. The fish production was 1.4 million $\mathrm{t}$ by 2014 but is forecasted to reach two million $\mathrm{t}$ by 2020 [21]. The production has increased strongly in the Mekong Delta in Vietnam, especially the regions close to the sea.

The saline intrusion caused by the decline of freshwater discharge from the upstream of the Mekong River, especially in the dry season, will severely affect the yield of aquaculture production. The most affected fish species is the Pangasius because it can only be cultivated exclusively in fresh water. There are only a few regions, such as An Giang and Dong Thap provinces, and northern parts of Can Tho and Vinh Long provinces of Vietnam, which will be less influenced [21].

The expansion of hydropower in the mainstream of the Mekong River will negatively impact the aquaculture production, which is declined in the freshwater flows caused by the saline intrusion, especially in the dry season. The electricity generation from dams the Mekong River in the dry season caused the water decline $[25-28,37,41,49,53,54]$, which apparently affect aquaculture production. Currently, most operations are concentrating on An Giang and Dong Thap areas, and in the northern parts of Can Tho, and Vinh Long provinces of Vietnam, which are remaining unaffected. The greater instruction of saline in the Mekong Delta in Vietnam will constrain the extent of freshwater fish production, including the Pangasius species [21]. It was calculated that if all 11 mainstream dams are constructed, the total loss in fish resources might be as high as $88,000 \mathrm{t}$, or $42 \%$ compared with the 2000 baseline [37].

\subsection{Economic Impacts on Fisheries}

It has been shown that fish yields will severely decrease due to the dam causing a blockage across the migratory routes of fish in the Mekong. White fish may be lost up to $276,847 \mathrm{t}$ in Vietnam and 178,169 t in Cambodia (Table 3) [21]. 
Table 3. Comparison of agricultural and fishery losses between Cambodia and Vietnam by species group.

\begin{tabular}{lccccccc}
\hline & White Fish & Grey Fish & Black Fish & $\begin{array}{c}\text { Marine/Estuarine } \\
\text { Fish }\end{array}$ & $\begin{array}{c}\text { Exotic } \\
\text { Fish }\end{array}$ & OAA & Total \\
\hline \multicolumn{7}{c}{ Cambodia } \\
\hline Fish losses (t) & 178,169 & 35,407 & 30,066 & 212 & 0 & 23,005 & 267,429 \\
\hline \multicolumn{7}{c}{ Vietnam } \\
\hline Fish losses (t) & 276,847 & 19,491 & 11,478 & 19,088 & 14,596 & 25,071 & 366,570 \\
\hline \multicolumn{7}{c}{ OAA: Other aquatic animals. }
\end{tabular}

Fish of 366,570 $t$ and 267,429 $t$ will be totally lost in Vietnam and Cambodia, respectively (Table 3). Grey and black fish in Cambodia are lost by greater quantity than in Vietnam, however, exotic fish and marine/estuarine fish, and other aquatic animals (OAA) will see a greater reduction in Vietnam than in Cambodia.

In Vietnam, fishery production accounts for 10\%-15\% of the GDP in the Agricultural, Fishery, and Forestry sectors, and the losses are between $6 \%$ and $9 \%$ of this sector alone [21]. In the case of Cambodia, fisheries contributed approximately 10\% GDP in 2012, the building of the 11 dams may result in a 30\% loss or $>3 \%$ GDP of the country. Although the total losses in Cambodia are smaller than in Vietnam, the vulnerable volume in Cambodia would be likely greater than in Vietnam.

If the proposed 11 dams are built, the current fish catch in the LMB would be about 2.1 million $t$ and will be reduced by 580,000 $t$ [62]. A total of 35\% of Mekong fisheries, including long-distance migratory fish, and they will need to adapt when the 11 Lower Mekong mainstream dams, plus the 30 dams proposed on the tributaries, are installed. This may cause a $90 \%$ loss of migratory fish under the 11-dam scenario [25]. The capture fishery loss forecast may reach 725,000 $t$ /year [63].

The current and future dams in China and proposed dams in Lao PDR and Cambodia on the Upper Mekong river will apparently accelerate the loss of wetland ecologies [22]. If all the proposed dams are built, more than $50 \%$ of the Lower Mekong River water will be captured in reservoirs and the seasonal flow of the river will be severely altered [5]. In addition, the balance between the South China Sea and the Mekong River is already shifting. For instance, recent droughts that occurred in the 2016's spring have allowed seawater to intrude farther upriver to cause serious problems for Vietnamese farmers [22].

\section{Impacts on Agriculture}

The Mekong Delta is a densely populated region of over 15 million people and 50,000 km² of fertile soil and is a leading exporter of rice, shrimp, and catfish [22]. The Mekong River Delta region of Vietnam contributes $15 \%$ of the world's rice export (5.7 million $t$ of milled rice in 2018 with a value of about USD 2.54 billion) [64,65]. The production of agriculture in Cambodia, as well as in Vietnam, remarkably correlates with the total agricultural production of the two countries. In Cambodia, agriculture accounts for $23.5 \%$ of the GDP and employs more than $40 \%$ of the workforce [66]. Rice is the first important food crop to bring the maximum income for farmers in Cambodia. During the period 2012-2013, the cultivating areas of wet season rice in Cambodia achieved 2.57 million ha (2.9 t/ha in average), to provide a 7.3 million $t$ of paddy rice. On the other hand, the area of dry land rice was just 0.48 million ha ( $4.4 \mathrm{t} / \mathrm{ha}$ ), to give 2.1 million $\mathrm{t}$ of rice. Cambodia has exported $626,225 \mathrm{t}$ of milled rice in 2018 [67]. In Vietnam, agriculture contributed approximately 15\% to the GDP in 2018 [66], the Mekong Delta includes only $25 \%$ of the agricultural land but provides more than 20 million $t$ of rice annually (50\% of the national rice output). It is also the largest source of employment [13]. Recently, canals, dikes, polders, and new rice varieties have transformed the landscape into high-yielding rice paddies and shrimp ponds [66]. The upstream hydropower development could induce saltwater intrusion in the Mekong Delta and thus dramatically reduce agricultural production [64].

The agricultural production in the Mekong Delta is associated with the availability of water, notably in the dry season. The available reservoir storage size is insufficient to provide water for 
agricultural production between the two seasons. Therefore, the nominated hydropower cascade could provide a great increase to crop production by recirculating water from the wet to the dry season $[13,60]$. Cambodia has planned to strengthen the irrigation in the dry season up to $50 \%$ (from 1.2 to 1.8 million ha) by the coming 20 years. The drainage extent is presently undergoing surveys in Cambodia, corresponding to the flood control in the undeveloped regions in Cambodia to hydropower expansion [60]. The building and operation of the nominated 11 dams would likely result in a negative influence on land use, cropping calendar, and agricultural production in the LMB [60,61].

Three changes in the drivers and causal factors described above were analyzed for their potential direct and indirect impacts on the livelihoods of the people in the Cambodia and Vietnam [21], focusing on: (i) Exposure to flooding, assesses potential impacts of changes in river system flows and velocities resulting in changes in depth and extent of river and floodplain, (ii) exposure to increased salinity, assesses changes in river system flows and velocities resulting in changes in extent and timing of salinity incursions, (iii) changes in river sediment flows and water quality, assesses impacts of these drivers on livelihood via changes in agriculture, fisheries, and economics, (iv) for the Vietnam Delta, indicators for livelihoods impacts from hydropower development are based on the estimated exposure to water level and salinity intrusion changes, as well as the anticipated changes to household income. For Cambodia, the indicators that have been identified include exposure to hydraulic changes as well as changes to household income from affected fishery activities.

The impacts of hydropower development, climate change, and sea-level rise in the maximum case would decrease up to $90 \%$ delta sedimentation and $95 \%$ the sediment reaching the sea, which apparently has caused a severe reduction in agricultural production and fisheries [68].

\subsection{Crop Production}

Agriculture provides livelihoods for more than $75 \%$ of the population of the LMB. The growth of the population in the region was nearly $45 \%$ between 1980 and 2000 and expected to continuously grow for the next 20 years, which has caused pressure on food production [27]. The dam construction will likely influence the seasonally inundated floodplains and wetlands close to Tonle Sap Lake and the Mekong Delta region [69-71].

\subsubsection{Impact on Rice Production}

The hydropower development in the LMB could lead to a decrease of $2.3 \%$ in rice production in Vietnam and 3.7\% in Cambodia [21]. The decline in production in both countries was primarily due to the changes in sediment loading. In Vietnam, the sediment decrease was 2.4 million $t$ (2.4 million $\mathrm{t}$ or $74 \%$ of silt, and only 0.02 million $\mathrm{t}$ or $1 \%$ of clay), whilst the amounts for Cambodia are approximately 12.5 million $\mathrm{t}(12.3$ million $\mathrm{t}$ or $74 \%$ of silt, and a minor amount of 0.2 million $\mathrm{t}$ or $3 \%$ of clay). Changes in flood patterns, salinity, and water levels intrusion did not have any impact on rice production [21]. Although climate change might strongly influence rice production [65], the dam construction negatively affects rice production in the LMB, and current government policies prohibit rice paddy farmers adapting to these changes [72]. Mainuddin and Kirby [73] indicated that there is a requirement of crop production stabilization projected to the increase of population by 2030 . The analysis of Berg et al. [74] revealed that the majority of rice farmers in the Mekong Delta were willing to reduce rice production and replace by other ecosystem services to lessen the effect caused by dam construction as well as climate change.

\subsubsection{Impacts on Maize Production}

Although the production of upland crops such as maize, sugarcane, and cassava in Thailand and Vietnam is greater than Cambodia and Lao PDR [73], the maize production in the LMB region was found to receive greater vulnerable impact than to rice production. Maize production in the Mekong Delta in Cambodia and Vietnam would be reduced by $10 \%$ and 21\%, respectively [21]. The principal 
influence on rice and maize production strongly depends on sediment reduction, inundation, and salinity changes.

\subsection{Economic Impacts on Agriculture}

Total economic productivity in the LMB countries, including Cambodia, Thailand, and Vietnam, are dominated by rice, with the exception of Lao PDR. Economic productivity of upland crops in highest in Lao PDR, followed by Vietnam, Cambodia, and Thailand [73]. In both Cambodia and Vietnam, the direct losses in gross revenue, total economic output, as well as GDP in fishery is higher than those in agriculture (Table 4). The total direct reduction in gross revenue in Vietnam (660.7 million USD) is much greater than Cambodia (457.1 million USD). However, loss to GDP in Cambodia (410.2 million USD) is much larger than in Vietnam (224.2 million USD) [21].

Table 4. Comparison of agriculture and fishery losses between Cambodia and Vietnam.

\begin{tabular}{|c|c|c|c|c|c|c|}
\hline & $\begin{array}{l}\text { Direct Losses in } \\
\text { Gross Revenue }\end{array}$ & \multicolumn{2}{|c|}{ Total Economic Output Loss } & \multicolumn{2}{|c|}{ Loss to GDP } & $\begin{array}{c}\text { Total Loss }(\% \\
\text { Regional/National } \\
\text { GDP) }\end{array}$ \\
\hline \multicolumn{7}{|c|}{ Cambodia } \\
\hline Agriculture (Million USD) & 54.5 & \multicolumn{2}{|c|}{84.0} & \multicolumn{2}{|c|}{84.0} & \multirow{3}{*}{3.7} \\
\hline Fishery (Million USD) & 402.6 & \multicolumn{2}{|c|}{660.5} & \multicolumn{2}{|c|}{326.2} & \\
\hline Total (Million USD) & 457.1 & \multicolumn{2}{|c|}{744.5} & \multicolumn{2}{|c|}{410.2} & \\
\hline & & $\begin{array}{l}\text { Mekong } \\
\text { Delta }\end{array}$ & Nation & $\begin{array}{l}\text { Mekong } \\
\text { Delta }\end{array}$ & Nation & \multirow{3}{*}{0.3} \\
\hline Agriculture (Million USD) & 128.2 & 264.7 & 270.8 & 57.1 & 58.8 & \\
\hline Fishery (Million USD) & 532.5 & 879.0 & 969.8 & 146.1 & 165.4 & \\
\hline
\end{tabular}

Total percentage of national GDP losses, including both fishery and agriculture [21].

With a total reduction of 1,143.7 million USD in the Mekong Delta, the economic activity will be reduced by 1,240.6 million USD at the national level [21]. The GDP reduction in the region is 203.2 million USD for the Mekong Delta and approximately 224.2 million USD for the country. These figures are remarkable, but the overall losses would be 3.7 and $0.3 \%$ in regional/national GDP in Cambodia and Vietnam, respectively. The total economic output loss in Cambodia achieves nearly 744.5 million USD in Cambodian GDP [21].

The total damage from fisheries and agriculture shows a significant influence on the Vietnamese Delta. Direct deficit surpasses 660.7 million USD and this could reduce the national economy over 1,143 million USD. The reduction may amount to approximately $0.3 \%$ of the national GDP of Vietnam. These consequences strongly affect the entire economy across the delta in Vietnam. It reveals that both fishers and farmers downstream of the Mekong River must urgently find measures to ease and adapt to these unstable conditions (Table 4) [21].

Similarly, the total macroeconomic impacts of fisheries and agriculture will negatively impact the Cambodian economy. The level of losses may exceed 457.1 million USD to result in a macroeconomic impact across Cambodia of over 744.5 million USD. The impact on GDP would amount to a loss of approximately 410.2 million USD or a 3.7\% reduction of Cambodian GDP (Table 4). The anticipated impact from the fishery and agriculture losses will affect the countries growth. The losses in fisheries will affect the integrated national industry development of Cambodia. Farming structures of the country, especially in paddy growing regions near the Vietnamese border, will also receive remarkable damage. The scale of reduction in some rural regions could be greater than $90 \%$ of yields to alert the collapse of fishery and agriculture production there [21]. Dung et al. [75] suggest that management of flood-tolerant water will benefit the sustainability of the Mekong Delta to reduce harmful effects from dam constructions on the upstream of the Mekong River as well as from climate change. 


\section{Tradeoff Between Electricity Generation and Ecosystems in the Lower Mekong Basin}

If built, the proposed 11 dams would generate approximately 15,000 MW of power, which may provide $8 \%$ of demand of the region by 2025 [3]. The gross income from hydropower generation may reach 3.7 billion USD per year. The annual income of Lao PDR and Cambodia may gain $18 \%$ and $4 \%$ of 2009 gross domestic product, respectively [2]. However, this study counters that the reduced fisheries, inundation of river banks, and loss of nutrients for agricultural soil might be equivalent to 500 million USD per year. In addition, the national population of Lao PDR and Cambodia would lose up to $30 \%$ of their annual protein intake or 2.1 million people of the two countries will suffer direct and indirect losses to their livelihoods [8]. Thailand and Lao PDR will be the beneficiaries whilst Cambodia and Vietnam would bear the principal cost of hydropower developments [25]. The total external cost of 11 planned mainstream hydropower projects in the LMB may amount to 18 billion USD, which is clearly an economic burden of the region [25]. Furthermore, project developers and electricity importers for dams in the Mekong River would benefit, but the farmers, and fishing communities would suffer many kinds of losses [62].

The total annual reduction in fisheries might be worth 500 million USD, however, $54 \%$ of ecological diversity will disappear $[60,61]$. The losses of agricultural land might be approximately 25.1 million USD, reduced nutrient loading would be 24 million USD. However, Lao PDR would be the most beneficial country because the majority of dam projects are located in Lao PDR (Figure 1, Tables 1 and 2). Lao PDR might receive 70\% export revenue (2.6 billion USD /year), whilst Cambodia might also get 30\% (1.2 billion USD /year). However, the modeled results of VMNRE [21] highlighted that the economic benefits of 22,558 million USD would arise for Lao PRD, 4,410 million USD in Thailand, 2,237 million USD in Cambodia, and 4,151 million USD in Vietnam. However, the economic losses in vulnerable fishery and agriculture might be a total of 3,041 million USD compared to the base line. Cambodian capture fisheries sorely count for more than $3 / 4$ of these losses, whilst the other three countries, including Lao PDR, Thailand and Vietnam, contribute approximately another one third [21].

The tradeoff analysis concluded that the forecasted loss of capture fisheries, sediment, or nutrients and social mitigation costs measured by NPV (Net Present Value) at a 10\% discount rate were greater than the benefits from electricity generation, improved irrigation, and flood control of the region [62]. In detail, the hydropower benefit (NPV of 6,650 million USD) might be earned from all the proposed dams on the mainstream and the 30 tributary projects, but the total economic impact might reach 7,329 million USD [25]. Several previous reports alerted that all countries of the region would benefit from hydropower development, but in reality, there would be a significant negative economic impact on Cambodia and Vietnam [13,15,60,62]. Different scenarios were formulated based on the water-related development plans of each individual country, including (i) Definite Future Situation (DFS), referring to the cumulative impact assessment occurring up to 2015 with dams on the Lancang and 26 tributary reservoir development in the LMB, (ii) Foreseeable Future Situation (FFS), referring to the transboundary impact assessment including 1.6 million ha irrigation expansion and 30 planned tributary dams, plus 11 planned mainstream dams up to 2030, and (iii) Long-term Future Situation (LFS), referring to the impact assessment of water resources development up to 2050 [25]. The total capital investment for FFS is approximately 50 billion USD in 2017 price [25].

The distribution of costs and benefits between MB countries was calculated. In detail, a benefit split was assumed to be $30 \%$ for the host country and $70 \%$ for the country providing funds or importing the electricity [25]. The hydropower benefit might be a shared 23\% for Lao PDR, $47 \%$ for Thailand, 5\% for Cambodia, and 25\% for Vietnam. However, this study indicated that Lao PDR and Thailand in any scenario always earned the most benefits, but Cambodia and Vietnam would suffer large economic impacts [25]. The distribution of costs and benefits among the LMB countries is needed to clarify as other countries such as China, France, South Korea, Malaysia, and Norway did [25]. The analysis of Galipeau et al. [8] on the dam-induced displacement of agricultural livelihoods Yunnan Province, China, shows that the tradeoff of receiving wage income for reduced landholdings causes a significant vulnerability for the affected houses of the Mekong River Basin. 
In recent years, the construction of hydropower dams has been occurring at an unprecedented rate to affect about $50 \%$ of all large rivers, including the Mekong River [16,76,77]. Although the dam construction may bring some desirable socioeconomic progress, but many risks to ecosystems and environmental services, including fish production and biodiversity, have not been seriously considered [16]. Though the Mekong River and its tributaries are affected by climate change and anthropogenic stressors, the construction of the proposed dams will continuously dominate the impacts on migratory fish [6]. The open water area of the Tonle Sap Lake has declined in recent 15 years due to the dam construction on the mainstream of the Mekong River, much more than effects due to climate change [78]. A tradeoff analysis is required to search for an optimized nature-based solution for the Tonle Sap Lake region [78]. The analysis of Ziv et al. [16] also indicated that the hydropower generation, which is planned to be exported from Lao PDR to Thailand and Vietnam, would have strong and nonlinear tradeoffs with floodplains fishery production.

\section{Lessons from other Regions}

The environmental challenges such as loss of wetlands, flood disasters, and poor water quality, occurred as documented in the Mekong River, are also being experienced in the Mississippi, the Yangtze, and the Nile [4,5]. Hydropower has been a leading source of renewable energy worldwide, as of 2016, it accounted for $>71 \%$ of this global renewable energy supply [1]. The construction of large dams in the US and Europe was popular between 1920 and 1970, but afterwards dam development slowed as the best sites for dams were already built and growing environmental and social concerns made the costs unacceptable [1]. The hydropower industry shifted to building dams in developing countries since the 1970s, starting from the Mekong River Basin, the Amazon River Basin, and the Congo River Basin [1]. In the US alone, there are over 82,000 large dams built, but since the late 1960s, big dams were stopped being built in developed countries, and were even being removed, for instance, 3450 dams have been removed to date in Sweden, Spain, Portugal, and the United Kingdom, Switzerland, and France [1]. In contrast, in recent decades, giant dams are being constructed in developing countries which repeatedly face similar problems caused by big dams in the United States and European nations: river ecology disruption, substantial deforestation, aquatic and terrestrial biodiversity loss, and reduction of agriculture production and water quality $[1,16,37]$. It is reported that $>3,700$ dams that produce more than $1 \mathrm{MW}$ are either planned or under construction, primarily in developing countries [4].

The Amazon Basin, an area of six million $\mathrm{km}^{2}$, has planned to build 147 dams, in which 65 are in Brazil $[1,79]$. However, Brazil is also investing in hydropower development at $180 \mathrm{GW}$ and $20 \mathrm{GW}$ in Bolivia and Peru, respectively [1,79]. Brazil is one of the maximal hydroelectric potential in the world with $240 \mathrm{GW}$, in which $41 \%$ is from the Amazon Basin. Therefore, the hydropower construction will be continuously constructed in Brazil, although it will strongly affect biodiversity ecosystem along with a rich diversity of ethnic and the livelihoods of million people [1]. There are 2300 fish species in the Amazon Basin, the most abundant in the world, followed by the Congo Basin with 1269 species, whilst the Mekong ranks third with 599 species. The fish species on all of these River Basins have been seriously damaged by the dam construction [1,80-82].

The Congo River is the second-longest river in Africa $(4700 \mathrm{~km})$ after the Nile River, as well as the second-largest flow $\left(42,000 \mathrm{~m}^{3} / \mathrm{s}\right)$, after the Amazon [1]. The construction of the Inga dam produces up to 40,000 MW of electricity (>twice the power generation of the TGD in China and $>1 / 3$ of the total electricity being produced in Africa). However, the energy production from the Inga dam is planned to be exported to South Africa to cater to mining companies rather than improving the lives of locals, and the impacts on environment and diversity have not been well evaluated [83].

The construction of dams on the main streams and tributaries was reported to cause dramatic water decline in Chinese rivers, including the Yellow River and the Yangtze River [1,84]. The Chinese dams in the Upper Mekong River were reported to cause changes in the water flow in the Lower Mekong River [84]. The building of dams in the Upper Mekong River has threatened the fish migratory 
and diversity, as well as fisheries in both the Upper and Lower Mekong River [85]. Similar to what is happening in the Mekong River, the deltas of the Mississippi, the Yangtze, and the Nile are also experiencing loss of wetland, flood disasters, poor water quality, reduced sediments from climate changes, as well as dam construction [22,86]. Nearly $80 \%$ (4.8 billion) of the world's population by the year 2000 lives in areas where either incident human water security or biodiversity that exceeds the $75 \%$ percentile [87]. The hydrology action threatened human water security and biodiversity in both upstream and downstream of many rivers worldwide [87]. Over 30 of the 47 largest rivers in the world, which collectively discharge half of the global runoff to the ocean show at least moderate threat levels $(>0.5)$, whilst eight rivers (for human water security) and fourteen (for diversity) display very high treat $(>0.75)$ [87]. Kano et al. [88] reported that the fish biodiversity of 363 fish species projected on the 81 dam-building scenarios in the Indo-Burma region was strongly affected by dam construction than climate change. In rivers such as Ebro, Mississippi, Indus, and Yangtze, sediment discharge is below their pre-human levels, whilst the Nile and Colorado rivers, present-day sediment discharge almost turns zero [89]. The Yangtze River ranks ninth globally in term of drainage area $\left(1.8\right.$ million $\left.\mathrm{km}^{2}\right)$, third in length $(6300 \mathrm{~km})$, fifth in water discharge $\left(900 \mathrm{~km}^{3} / \mathrm{yr}\right)$, fourth in sediment flux $(500 \mathrm{mt} / \mathrm{yr})$ and first in the watershed population (450 million) [90], but more than 50,000 dams have been built throughout the Yangtze's watershed [91]. In 2003, the world's largest hydropower project, the Three Gorges Dam (TGD) began its operation. The study of Yang et al. [90] reported that mean sediment flux reduced by $71 \%$ between 1950 and 1968 and the post-TGD decade. Approximately 30\% of the total decline attributed to the TGD, whilst $5 \%$ and $14 \%$ of these declines to the precipitation change and the remaining to other dams and soil conservation within the drainage basin. The annual sediment of the Yellow Rivers is at $1.6 \mathrm{Gt} / \mathrm{yr}$, but it has reduced to 0.8 and $0.4 \mathrm{Gt} / \mathrm{yr}$ by the $1980 \mathrm{~s}$ and $1990 \mathrm{~s}$, respectively [92].

\section{Conclusions}

The development of hydropower dams would increase the vulnerability of communities relying on fisheries for income and nutrition in Cambodia and Vietnam $[93,94]$. The planned new hydropower dams will have harmful impacts on fisheries by blocking migration routes and trapping nutrient and sediment flows [16,94-96]. The information on how hydropower-induced alternations from constructions of the proposed dams on the mainstream the Mekong River affect the LMB's hydrology, habitats, agricultural, and fishery production is crucial for anticipating and mitigating their negative influence. Among numerous surveys and studies conducted so far on this issue, the extensive survey conducted by VNMRE [32] between 2012 and 2015, which covered approximately 106,400 $\mathrm{km}^{2}$ and included 13 provinces in Vietnam and 14 provinces in Cambodia has provided essential information which is highlighted in this paper. Although all the four countries in the LMB, especially Lao PRD, will receive benefits from the electricity generation in the next 25 years, significant losses in fishery and agriculture production are foreseen. The fishery production in Cambodia will be the most vulnerable (approximately 70\% of total losses in LMB), followed by the Mekong Delta region in Vietnam, whilst Lao PDR and Thailand show the least vulnerability. The principal population in Cambodia is dependent on fishery production, and the habitats and livelihoods of millions of people living in the LMB of the four countries will be directly affected. Therefore, further assessments on ecological, livelihood, agriculture, and fishery-relevant impacts should be carefully examined and integrated into dam operations. Among the proposed built dams, the reassessment of several dams, as well as new regional agreement on tributary development of the Mekong River Basin, are required [16].

There is a need to reduce the dependence on hydropower generation in developing countries and combine it with other energy sources to reduce the negative environmental, behavioral, cultural, and socioeconomic externalities causing from large dams [1]. The cost of electricity generation from wind and solar is decreasing as improvements to efficiencies are made, and these have a competitive price for the energy produced. With the significant economic growth observed in many developing countries, it is possible to gradually remove hydropower away from big dams and combine it with 
instream turbines and diversified energies which do not disrupt stream ecology and fisheries and the live of resident on the great rivers in the world, including the Mekong River [1,97]. The negative social and environmental externalities caused by big dams should be carefully analyzed and studied before construction.

Author Contributions: All authors of this manuscript share adequately work on the collection of data and writing this manuscript. All authors have read and agreed to the published version of the manuscript.

Funding: This work receives no external funding.

Acknowledgments: The authors thank Breana Venneman for English editing on this manuscript.

Conflicts of Interest: The authors declare no conflict of interest.

\section{References}

1. Moran, E.F.; Lopez, M.C.; Moore, N.; Muller, N.; Hyndman, D.W. Sustainable hydropower in the 21st century. Proc. Natl. Acad. Sci. USA 2018, 115, 11891-11898. [CrossRef] [PubMed]

2. Fox, J.; Wood, J.L. Dry-season flood-recession rice in the Mekong delta: Two thousand years of sustainable agriculture? Asian Perspect. 2007, 38, 37-50.

3. Grumbine, R.E.; Xu, J.C. Mekong hydropower development. Science 2011, 332, 178-179. [CrossRef] [PubMed]

4. Zarfl, C.; Lumsdon, A.; Berlekamp, J.; Tydecks, L.; Tockner, K. A global boom in hydropower dam construction. Aquat. Sci. 2015, 77, 161-170. [CrossRef]

5. Olson, K.R.; Morton, L.W. Water rights and fights: Lao dams on the Mekong River. J. Soil Water Conserv. 2018, 73, 35-41. [CrossRef]

6. International Commission on Large Dams. World Register of Dams. 2011. Available online: http: //www.icold-cigb.org (accessed on 22 February 2020).

7. The World Bank. Database World Development Indicators “Electricity Production from Renewable Sources, Excluding Hydroelectric (kWh)". 2014. Available online: http://data.worldbank.org/indicator/EG.ELC. RNWX.KH (accessed on 22 February 2020).

8. Galipeau, B.A.; Ingman, M.; Tilt, B. Dam-induced displacement and agricultural livelihoods in China's Mekong Basin. Hum. Ecol. 2013, 41, 437-446. [CrossRef]

9. Rex, W.; Foster, V.; Lyon, K.; Bucknall, J.; Liden, R. Supporting Hydropower: An Overview of the World Bank Group's Engagement; World Bank Group: Washington, DC, USA, 2014.

10. Scudder, T. Development-induced community resettlement. In New Directions in Social Impact Assessment Conceptual and Methodological Advances; Vanclay, F., Esteves, A., Eds.; Edward Elgar Publishing Limited: Cheltenham, UK, 2011; pp. 186-201.

11. Mahe, G.; Lienou, G.; Descroix, L.; Bamba, F.; Paturel, J.E.; Laraque, A.; Meddi, M.; Haibaieb, H.; Adeaga, O.; Dieuin, C.; et al. The river of Africa: Witness of climate change and human impact on the environment. Hydrol. Process. 2013, 27, 2105-2114. [CrossRef]

12. Hecht, J.S.; Lacombe, G.; Arias, M.E.; Dang, T.D.; Piman, T. Hydropower dams of the Mekong River Basin: A review of their hydrological impacts. J. Hydrol. 2019, 568, 285-300. [CrossRef]

13. Mekong River Commission (MRC). Assessment of Basin-Wide Development Scenarios-Main Report; Mekong River Commission: Vientiane, Laos, 2011; Available online: http://www.mrcmekong.org/assets/Publications/ basin-reports/BDP-Assessment-of-Basinwide-Dev-Scenarios-2011.pdf (accessed on 22 February 2020).

14. Fox, C.A.; Sneddon, C.S. Political borders, epistemological boundaries, and contested knowledges: Constructing dams and narratives in the Mekong River Basin. Water. 2019, 11, 413. [CrossRef]

15. Mekong River Commission (MRC). State of the Basin Report 2018; Mekong River Commission: Vientiane, Laos, 2019; Available online: http://www.mrcmekong.org/assets/Publications/SOBR-v8_Final-for-web.pdf (accessed on 22 February 2020).

16. Ziv, G.; Baran, E.; Nam, S.; Rodriguez-Iturbe, I.; Levin, S.A. Trading-off fish biodiversity, food security, and hydropower in the Mekong River Basin. Proc. Natl. Acad. Sci. USA 2012, 109, 5609-5614. [CrossRef]

17. Lynch, A.J.; Myers, B.J.E.; Chu, C.; Eby, L.A.; Falke, J.A.; Kovach, R.P. Climate change effects on North American inland fish populations and assemblages. Fisheries 2016, 41, 346-361. [CrossRef] 
18. Winemiller, K.O.; McIntyre, P.B.; Castello, L.; Fluet-Chouinard, E.; Giarrizzo, T.; Nam, S.; Baird, I.G.; Darwall, W.; Lujan, N.K.; Harrison, I.; et al. Balancing hydropower and biodiversity in the Amazon, Congo, and Mekong. Science 2016, 351, 128-129. [CrossRef] [PubMed]

19. Pittock, J.; Dumaresq, D.; Bassi, A.M. Modeling the hydropower food nexus in large river basins: A Mekong case study. Water 2016, 8, 425. [CrossRef]

20. Orr, S.; Pittock, J.; Chapagain, A.; Dumaresq, D. Dams on the Mekong River: Lost fish protein and the implications for land and water resources. Glob. Environ. Chang. 2012, 22, 925-932. [CrossRef]

21. Vietnam Ministry of Natural Resources and Environment (VMNRE). Study on the Impacts of Mainstream Hydropower on the Mekong River; HDR, Inc.: Englewood, CO, USA; Danish Hydrological Institute (DHI): Hørsholm, Denmark, 2015; Available online: https://www.mekongeye.com/wp-content/uploads/sites/2/2016/ 04/MDS-Final-Project-Report-Eng.pdf (accessed on 25 October 2019).

22. Olson, K.R.; Morton, L.W. Polder, dikes, canals, rice, and aquaculture in the Mekong Delta. J. Soil Water Conserv. 2018, 73, 83-89. [CrossRef]

23. International Energy Agency (IEA). International Energy Outlook-With Projections to 2040; IEA Office of Communications: Washington, DC, USA, 2016. Available online: https:/www.eia.gov/outlooks/ieo/pdf/ 0484(2016).pdf (accessed on 25 October 2019).

24. Montaña, C.G.; Ou, C.; Keppeler, F.W.; Winemiller, K.O. Functional and trophic diversity of fishes in the Mekong-3S river system: comparison of morphological and isotopic patterns. Environ Biol. Fish. 2020, 103, 185-200. [CrossRef]

25. Intralawan, A.; Wood, D.; Frankel, R.; Costanza, R.; Kubiszewski, I. Tradeoff analysis between electricity generation and ecosystem services in the Lower Mekong basin. Ecosyst. Serv. 2018, 30, 27-35. [CrossRef]

26. Dang, T.D.; Cochrane, T.A.; Arias, M.E.; Van, P.D.T. Future hydrological alterations in the Mekong Delta under the impact of water resources development, land subsidence and sea level rise. J. Hydrol. Reg. Stud. 2018, 15, 119-133. [CrossRef]

27. Pokhrel, Y.; Burbano, M.; Roush, J.; Kang, H.; Sridhar, V.; Hyndman, D.W. A review of the integrated effects of changing climate, land use, and dams on Mekong River hydrology. Water 2018, 10, 266. [CrossRef]

28. Fan, H.; He, D.; Wang, H. Environmental consequences of damming the mainstream Lancang-Mekong River: A review. Earth Sci. Rev. 2015, 146, 77-91. [CrossRef]

29. Yu, X.; Geheb, K. State of Knowledge: Hydropower Environmental Mitigation Measures on the Lancang River; State of Knowledge Series 8; CGIAR Research Program on Water, Land and Ecosystems (WLE): Vientiane, Laos, 2017.

30. Grumbine, R.E.; Dore, J.; Xu, J.C. Mekong hydropower: Drivers of change and governance challenges. Front. Ecol. Environ. 2012, 10, 91-98. [CrossRef]

31. Johnston, R.M.; Kummu, M. Water resources models in the Mekong Basin: A review. Water Resour. Manag. 2012, 26, 429-455. [CrossRef]

32. McElwee, P.; Horowitz, M. Environment and Society in the Lower Mekong Basin: A Landscaping Review; Institute for Development Anthropology: Binghamton, NY, USA, 1999.

33. Trung, L.D.; Duc, N.A.; Nguyen, L.T.; Thai, T.H.; Khan, A.; Rautenstrauch, K.; Schmidt, C. Assessing cumulative impacts of the proposed Lower Mekong Basin hydropower cascade on the Mekong River floodplains and delta-Overview of integrated modeling methods and results. J. Hydrol. 2018. [CrossRef]

34. Kummu, M.; Lu, X.X.; Wang, J.J.; Varis, O. Basin-wide sediment trapping efficiency of emerging reservoirs along the Mekong. Geomorphology 2010, 119, 181-197. [CrossRef]

35. Water, Land, and Ecosystems-Mekong. Mekong Hydropower Map and Portal. 2017. Available online: https://wle-mekong.cgiar.org/maps/ (accessed on 23 February 2020).

36. Dore, J.; Xiaogang, Y.; Yuk-shing, K. China's energy reforms and hydropower expansion in Yunnan. In Democratizing Water Governance in the Mekong Region; Lebel, L., Dore, J., Daniel, R., Koma, Y.S., Eds.; Silkworm Books: Chiang Mai, Thailand, 2007; pp. 55-92.

37. Stone, R. Mayhem on the Mekong. Science 2011, 333, 815-818. [CrossRef]

38. Dugan, P.J.; Barlow, C.; Agostinho, A.; Baran, E.; Cada, G.F.; Chen, D.; Cowx, I.G.; Ferguson, J.W.; Jutagate, T.; Mallen-Cooper, M.; et al. Fish migration, dams, and loss of ecosystem services in the Mekong Basin. AMBIO 2010, 39, 344-348. [CrossRef]

39. Sabo, J.L.; Ruhi, A.; Holtgrieve, G.W.; Elliott, V.; Arias, M.E.; Ngor, P.B.; Räsänen, T.A.; So, N. Designing river flows to improve food security futures in the Lower Mekong Basin. Science 2017, 358, 1053. [CrossRef] 
40. Zhang, C.; Ding, L.; Ding, C.; Chen, L.; Sun, J.; Jiang, X. Responses of species and phylogenetic diversity of fish communities in the Lancang River to hydropower development and exotic invasions. Ecol. Indic. 2018, 90, 261-279. [CrossRef]

41. Lyon, S.W.; King, K.; Polpanich, O.; Lacombe, G. Assessing hydrologic changes across the Lower Mekong Basin. J. Hydrol. Reg. Stud. 2017, 12, 303-314. [CrossRef]

42. Kraitud, N. Hydropower projects in Thailand. Available online: http://www.mrcmekong.org/assets/Uploads/ 1.-Hydropower-plan-Thailand.pdf (accessed on 22 February 2020).

43. Baran, E.; Myschowoda, C. Dams and fisheries in the Mekong basin. Aquat. Ecosyst. Health 2009, 12, $227-238$. [CrossRef]

44. Valbo-Jorgensen, J.; Coates, D.; Hortle, K. Fish diversity in the Mekong River basin. In Aquatic Ecology, the Mekong: Biophysical Environment of an International River Basin; Cambell, I.C., Ed.; Academic Press: Cambridge, MA, USA, 2009; pp. 161-196. [CrossRef]

45. Ferguson, J.W.; Healey, M.; Dugan, P.; Barlow, C. Potential effects of dams on migratory fish in the Mekong River: Lessons from salmon in the Fraser and Columbia rivers. Environ. Manag. 2011, 47, 141-159. [CrossRef] [PubMed]

46. Hortle, K.G. Consumption and the Yield of Fish and Other Aquatic Animals from the Lower Mekong Basin; MRC Technical Paper No. 16; Mekong River Commission: Vientiane, Laos, 2007.

47. Halls, A.S.; Moyle, P.B. Comment on "designing river flows to improve food security futures in the Lower Mekong Basin". Science 2018, 361, eaat1989. [CrossRef]

48. Halls, A.S.; Paxton, B.R.; Hall, N.; Hortle, K.G.; So, N.; Chheng, P.; Peng, B.N.; Boonsong, S. Integrated Analysis of Data from MRC Fisheries Monitoring Programmes in the Lower Mekong basin; MRC Technical Paper No. 33; Mekong River Commission: Phnom Penh, Cambodia, 2013.

49. Piman, T.; Lennaerts, T.; Southalack, P. Assessment of hydrological changes in the Lower Mekong Basin from basin-wide development scenarios. Hydrol. Process. 2013, 27, 2115-2125. [CrossRef]

50. Pitman, T.; Cochrane, T.A.; Arias, M.E.; Green, A.; Dat, N.D. Assessment of flow changes from hydropower development and operations in Sekong, Sesan and Srepok Rivers of the Mekong Basin. J. Water Resour. Plan. Manag. 2013, 139, 723-732. [CrossRef]

51. Arias, M.E.; Cochrane, T.A.; Kummu, M.; Lauri, H.; Holtgrieve, G.W.; Koponen, J.; Piman, T. Impacts of hydropower and climate change on drivers of ecological productivity of Southeast Asia's most important wetland. Ecol. Model. 2014, 272, 252-263. [CrossRef]

52. Anderson, E.P.; Jenkins, C.N.; Heilpern, S.; Maldonado-Ocampo, J.A.; Carvajal-Vallejos, F.; Encalada, A.C.; Rivadeneira, J.F.; Hidalgo, M.; Cañas, C.M.; Ortega, H.; et al. Fragmentation of Andes-to-Amazon connectivity by hydropower dams. Sci. Adv. 2018, 4, 1642. [CrossRef] [PubMed]

53. Arias, M.E.; Cochrane, T.A.; Elliott, V. Modelling future changes of habitat and fauna in the Tonle Sap wetland of the Mekong. Environ. Cons 2014, 41, 165-175. [CrossRef]

54. Arias, M.E.; Cochrane, T.A.; Lawrence, K.; Killeen, T.J.; Farrell, T.A. Paying the forest for electricity: A modelling framework to market forest conservation as payment for ecosystem services benefiting hydropower generation. Environ. Conserv. 2011, 38, 473-484. [CrossRef]

55. Baran, E.; Larinier, M.; Ziv, G.; Marmulla, G. Review of the Fish and Fisheries Aspects in the Feasibility Study of the Environmental Impact Assessment of the Proposed Xayaburi Dam on the Mekong Mainstream; World Wildlife Fund Greater Mekong: Bangkok, Thailand, 2011; Available online: http://assets.panda.org/downloads/wwf_ xayaburi_dam_review310311.pdf (accessed on 22 February 2020).

56. Chea, R.; Guo, C.; Grenouillet, G.; Lek, S. Toward an ecological understanding of a flood-pulse system lake in a tropical ecosystem: Food web structure and ecosystem health. Ecol. Model. 2016, 323, 1-11. [CrossRef]

57. Hecht, J.S.; Lacombe, G. The Effects of Hydropower Dams on the Hydrology of the Mekong Basin; State of Knowledge Series 5; CGIAR Research Program on Water, Land and Ecosystems (WLE): Vientiane, Laos, 2014.

58. Koponen, J.; Lamberts, D.; Sarkkula, J.; Inkala, A.; Junk, W.J.; Halls, A.S.; Kshatriya, M. Primary and Fish Production Report (Final Report); DMS—Detailed Modelling Support Project; MRC Information Knowledge Management Programme/Finnish Environment Institute (SYKE)/EIA Centre of Finland Ltd.: Espoo, Finland, 2010.

59. Kondolf, G.M.; Schmitt, R.J.P.; Carling, P.; Darby, S.; Arias, M.; Bizzi, S.; Castelletti, A.; Cochrane, T.A.; Gibson, S.; Kummu, M.; et al. Changing sediment budget of the Mekong: Cumulative threats and management strategies for a large river basin. Sci. Total Environ. 2018, 625, 114-134. [CrossRef] 
60. Mekong River Commission (MRC). Basin Development Plan Programme, Phase 2. Technical Assessment Note 11: Impacts on Fisheries; Mekong River Commission: Vientiane, Laos, 2010.

61. International Centre for Environmental Management (ICEM). Strategic Environmental Assessment of Hydropower on the Mekong Mainstream; Final Report; Mekong River Commission: Hanoi, Viet Nam, 2010.

62. Intralawan, A.; Wood, D.; Frankel, R. Working Paper on Economic Environmental and Social Impact of Hydropower Development in the Lower Mekong Basin; Natural Resources and Environmental Management Research and Training Center: Chiang Rai, Thailand, 2015; pp. 1-13.

63. Nam, S.; Phommakone, S.; Vuthy, L.; Samphawamana, T.; Son, N.H.; Khumsri, M.; Bun, N.P.; Sovanara, K.; Degen, P.; Starr, P. Catch and Culture, Mekong River Commission, Fisheries Research and Development in the Mekong Region. 2015, Volume 21. No. 3. Available online: http://www.mrcmekong.org/assets/Publications/ Catch-and-Culture/CatchCultureVol-21.3.pdf (accessed on 22 February 2020).

64. Pearse-Smith, S.W.D. The impact of continued Mekong Basin hydropower development on local livelihoods. Cons. J. Sustain. Dev. 2012, 7, 73-86.

65. Quyen, N.H.; Duong, T.H.; Yen, B.T.; Sebastian, L. Impact of Climate Change on Future Rice Production in the Mekong River Delta; Climate Change, Agriculture and Food Security (CCAFS): Frederiksberg, Denmark, 2018.

66. World Bank Group (World Bank). 2019. Available online: http://documents.worldbank.org (accessed on 22 February 2020).

67. Morton, L.W.; Olson, K.R. The pulses of the Mekong River Basin: Rivers and the livelihoods of farmers and fishers. J. Environ. Prot. 2018, 9, 431-459. [CrossRef]

68. Manh, N.V.; Dung, N.V.; Hung, N.N.; Kummu, M.; Merz, B.; Apel, H. Future sediment dynamics in the Mekong Delta floodplains: Impacts of hydropower development, climate change and sea level rise. Glob. Planet. Chang. 2015, 127, 22-33. [CrossRef]

69. Kummu, M.; Sarkkula, J. Impact of the Mekong river flow alteration on the Tonle Sap flood pulse. AMBIO 2008, 37, 185-192. [CrossRef]

70. Dudgeon, D. Large-scale hydrological changes in tropical Asia: Prospects for riverine biodiversity: The construction of large dams will have an impact on the biodiversity of tropical Asian rivers and their associated wetlands. BioScience 2000, 50, 793-806. [CrossRef]

71. Le, T.V.H.; Nguyen, H.N.; Wolanski, E.; Tran, T.C.; Haruyama, S. The combined impact on the flooding in Vietnam's Mekong river delta of local man-made structures, sea level rise, and dams upstream in the river catchment. Estuar. Coast. Shelf Sci. 2007, 71, 110-116. [CrossRef]

72. Kontgis, C.; Schneider, A.; Ozdogan, M.; Kucharik, C.; Tri, V.P.D.; Duc, N.H.; Schatz, J. Climate change impacts on rice productivity in the Mekong River Delta. Appl. Geogr. 2019, 102, 71-83. [CrossRef]

73. Mainuddin, M.; Kirby, M. Agricultural productivity in the lower Mekong Basin: Trends and future prospects for food security. Food Secur. 2009, 1, 71-82. [CrossRef]

74. Berg, H.; Soderholm, A.E.; Soderstrom, A.S.; Tam, N.T. Recognizing wetland ecosystem services for sustainable rice farming in the Mekong Delta, Vietnam. Sustain. Sci. 2017, 12, 137-154. [CrossRef]

75. Dung, T.D.; Halsema, G.; Hellegers, P.J.G.J.; Long, H.P.; Ludwig, F. Long-term sustainability of the Vietnamese Mekong delta in question: An economic assessment of water management alternatives. Agric. Water Manag. 2019, 223, 105703.

76. Lehner, B.; Liermann, R.; Revenga, C.; Vörösmarty, C.; Fekete, B.; Crouzet, P.; Doell, P.; Endejan, M.; Frenken, K.; Magome, J.; et al. High-resolution mapping of the world's reservoirs and dams for sustainable river-flow management. Front. Ecol. 2011, 9, 494-502. [CrossRef]

77. Nilsson CReidy, C.A.; Dynesius, M.; Revenga, C. Fragmentation and flow regulation of the world's large river systems. Science 2005, 308, 405-408. [CrossRef] [PubMed]

78. Lin, Z.; Qi, J. Hydro-dam-A nature-based solution or an ecological problem: The fate of the Tonle Sap Lake. Environ. Res. 2017, 158, 24-32. [CrossRef] [PubMed]

79. The Economist. The Rights and Wrongs of Belo Monte: Dams in Amazon. Available online: http://www.economist.com/news/americas/21577073-having-spent-heavily-make-worlds-thirdbiggest-hydroelectric-project-greener-brazil (accessed on 22 January 2020).

80. Fearnside, P.M. Emission from tropical hydropower and the IPCC. Environ. Sci. Policy 2015, 50, $225-239$. [CrossRef]

81. Mcgrath, D.G.; de Castro, F.; Futemma, C.; de Amaral, B.D.; Calabria, J. Fisheries and the evolution of the resource management on the lower Amazon floodplain. Hum. Ecol. 1993, 21, 167-195. [CrossRef] 
82. Sternberg, R. Damming the river: A changing perspective on altering nature. Renew. Sustain. Energy Rev. 2006, 10, 165-197. [CrossRef]

83. Green, N.; Sovacool, B.K.; Hancok, K. Grand designs: Assessing the Africa energy security implications of the Grand Inga Dam. Afr. Stud. Rev. 2015, 58, 133-158. [CrossRef]

84. Dai, S.B.; Lu, X.X. Sediment load change in the Yangtze River (Changjian): A review. Geomorphology 2014, 215, 60-73. [CrossRef]

85. Kang, B.; He, D.; Perrett, L.; Wang, H.; Hu, W.; Deng, W.; Wu, Y. Fish and fisheries in the Upper Mekong: Current assessment of the fish community, threats and conservation. Rev. Fish Biol. Fish. 2009, 19, 465-480. [CrossRef]

86. Biggs, D. Fixing the delta: History and the politics of hydraulic infrastructure development and conservation in the Mekong Delta. In Environmental Change and Agricultural Sustainability in the Mekong Delta; Stewart, M.A., Coclanis, P.A., Eds.; Springer: New York, NY, USA, 2011; pp. 35-44.

87. Vorosmarty, C.J.; McIntyre, P.B.; Gessner, M.O.; Dudgeon, D.; Prusevich, A.; Green, P.; Glidden, S.; Bunn, S.E.; Sullivan, C.A.; Liermann, C.R.; et al. Global threats to human water security and river biodiversity. Nature 2010, 467, 555. [CrossRef]

88. Kano, Y.; Dudgeon, B.; Nam, S.; Samejima, H.; Watanabe, K.; Grudpan, C.; Grudpan, J.; Magtoon, W.; Musikasinthorn, P.; Thanh, N.T.; et al. Impact of dams and global warming on fish biodiversity in the Indo-Burma hotspot. PLoS ONE 2016, 11, e0160151. [CrossRef] [PubMed]

89. Vorosmarty, C.J.; Meybeck, M.; Fekete, B.; Sharma, K.; Green, P.; Syvitsky, J. Anthropogenic sediment retention: Major global-scale impact from the population of registered impoundments. Glob. Planet. Chang. 2003, 39, 169-190. [CrossRef]

90. Yang, S.L.; Xu, K.H.; Milliman, J.D.; Yang, H.F.; Wu, C.S. Decline of Yangtze River water and sediment discharge: Impact from natural and anthropogenic changes. Sci. Rep. 2015, 5, 12581. [CrossRef] [PubMed]

91. Yang, S.L.; Milliman, J.D.; Li, P.; Xu, K. 50,000 dams later: Erosion of the Yangtze River and its delta. Glob. Planet. Chang. 2011, 75, 14-20. [CrossRef]

92. Walling, D.E. Human impact on land-ocean sediment transfer by the world's rivers. Geomorphology 2006, 79, 192-216. [CrossRef]

93. Allison, E.H.; Perry, A.L.; Badjeck, M.C.; Neil Adger, W.; Brown, K.; Conway, D.; Andrew, N.L. Vulnerability of national economies to the impacts of climate change on fisheries. Fish Fish. 2009, 10, 173-196. [CrossRef]

94. Hijioka, Y.E.; Lin, J.J.; Pereira, R.T.; Corlett, X.; Cui, G.E.; Insarov, R.D.; Lasco, E.L.; Surjan, A. Asia. In Climate Change 2014: Impacts, Adaptation, and Vulnerability. Part B: Regional Aspects; Contribution of Working Group II to the Fifth Assessment Report of the Intergovernmental Panel on Climate Change; Barros, V.R.C.B., Field, D.J., Dokken, M.D., Mastrandrea, K.J., Mach, T.E., Bilir, M., Chatterjee, K.L., Ebi, Y.O., Estrada, R.C., Genova, B., et al., Eds.; Cambridge University Press: Cambridge, UK; New York, NY, USA, 2014; pp. 1327-1370.

95. Baran, E.; Guerin, E. Dams, Changes in Sediment Load and Impact on Fish Resources in the Mekong: Approach and Way Forward; Report for the project "a climate resilient Mekong: Maintaining the flows that nourish life" led by the Natural Heritage Institute; World Fish Center: Phnom Penh, Cambodia, 2012.

96. Evers, J.; Pathirana, A. Adaption to climate change in the Mekong River Basin: Introduction to the special issue. Clim. Chang. 2018, 149, 1-11. [CrossRef]

97. Resch, G.; Held, A.; Faber, T.; Panzer, C.; Toro, F.; Haas, R. Potentials and prospects for renewable energies at global scale. Energy Policy 2008, 36, 4048-4056. [CrossRef]

(C) 2020 by the authors. Licensee MDPI, Basel, Switzerland. This article is an open access article distributed under the terms and conditions of the Creative Commons Attribution (CC BY) license (http://creativecommons.org/licenses/by/4.0/). 